\title{
PENGARUH PENGGUNAAN MEDIA TANAM HIDROPONIK TERHADAP PERTUMBUHAN DAN PRODUKTIVITAS TANAMAN TERONG (Solanum melongena)
}

\author{
Bakhtiar $^{1}$, Nehru $^{2}$ \\ Program Studi Pendidikan Biologi, STKIP Bima. Jalan Piere Tendean Kel. Mande Tel. Fax (0374) \\ 42801, Bima 84191, Indonesia \\ 1,2 Dosen Program Studi Pendidikan Biologi STKIP BIMA \\ (E-mail : $\underline{\text { bakhtiarbima43@gmail.com) }}$
}

\begin{abstract}
Abstrak: Penelitian ini bertujuan untuk mengetahui pengaruh penggunaan media tanam hidroponik terhadap pertumbuhan dan produktifitas tanaman Terong (Solanum melongena). Penelitian ini mengunakan Rancangan Acak Lengkap (RAL). Parameter pengamatanya adalah tinggi tanaman, lebar daun, jumlah daun, banyaknya cabang dan banyaknya buah dari setiap perlakuan yang ada. Penelitian dianalisis anova. Hasil penelitin menunjukkan bahwa: 1) penggunaan media tanaman hidroponik yang berbeda akan berpengaruh terhadap tinggi tanaman terong, ini dibuktikan dengan hasil pengamatan yang menunjukkan $f_{\text {hitung }}$ lebih besar dari $f_{\text {tabel. }}$. Hal ini didukung dengan hasil penelitian pada umur dua minggu nilai $F_{\text {Hitung }}>F_{\text {Tabel }}(8,13>4,07)$, empat minggu setelah tanam menunjukkan nilai $F_{\text {hitung }}$ sebesar 7,99 dengan perbandingan karena $F_{\text {Hitung }}(7,99)>F_{\text {Tabel }}(4,07)$ dan minggu keenam menunjukkan $\left.F_{\text {Hitung }}>F_{\text {Tabel }}(14,34>4,07) ; 2\right)$ penggunaan media tanam hidroponik yang berbeda akan berpengaruh terhadap jumlah daun tanaman terong, ini dibuktikan dengan hasil pengamatan terhadap jumlah daun tanaman terong pada umur dua minggu setelah tanam dengan nilai $F_{\text {Hitung }}>F_{\text {Tabel }}(17,00>4,07)$, sementara pada usia tanaman empat minggu setelah tanam menunjukkan nilai $F_{\text {hitung }}$ sebesar 7,99 dengan perbandingan karena $F_{\text {Hitung }}(7,58)>F_{\text {Tabel }}(4,07)$ dan minggu keenam setelah tanam menunjukkan $F_{\text {Hitung }}>F_{\text {Tabel }}(6,44>4,07)$.
\end{abstract}

Kata Kunci: Media Tanam, Hidroponik, Produktivitas Terong.

\section{PENDAHULUAN}

Terong merupakan tanaman sayuran yang biasa dimakan mentah sebagai lalap dan dimasak menjadi lauk. Sayuran yang mudah ditanam ini kaya serat, zat gizi, serta berkhasiat obat. Terung mudah diperoleh baik di pasar tradisional maupun pasar swalayan serta harganya murah. Ada beberapa jenis terung yang sering dijumpai, antara lain terung gelatik, terung kopek, terung craigi, terung jepang, terung medan dan terung bogor (Muchtadi, 2000).

Buah terung merupakan buah sejati tunggal dan berdaging tebal, lunak, serta tidak akan pecah bila buah telah masak. Daging buahnya tebal, lunak dan berair. Biji-biji terdapat bebas dalam daging buah (Rukmana, 1994). Buah mengantung tiap tangkai buah. Buah terung mempunyai bentuk yang beragam sesuai dengan varietasnya, bentuk yang dikenal 
meliputi panjang silindris, panjang lonjong, lonjong (oval), bulat lebar dan bulat. Khasiat terung dan jenis terung-terungan lainnya disebabkan oleh kandungan alkaloid solanin (Agus, 2008). Senyawa solasodin yang terdapat dalam tanaman Solanaceae dapat digunakan sebagai bahan baku kontrasepsi oral yaitu obat pencegah kehamilan yang digunakan dengan cara diminum sebagai contoh Solanum laciniatum mengandung solasodin $1,5 \%$ sampai 3\%, Solanum khasianum mengandung solasodin $3 \%$ dan Solanum gradiflorum mengandung solasodin 2,6\% (Soestasad, 2003).

Sejak manusia mengenal pertanian, tanah merupakan media tanam yang paling umum digunakan dalam bercocok tanam. Seiring dengan perkembangan jaman dan dipacu oleh keterbatasan lahan yang dimiliki seperti tanah yang sempit atau tanah yang tidak subur, orang mulai bercocok tanam dengan menggunakan media tanam bukan tanah, seperti air, pasir dan lain-lain (Wuryaningsih \& Darliah, 1994)

Hidroponik merupakan salah satu alternatif cara bercocok tanam tanpa menggunakan tanah sebagai media tanamnya (Siswad, 2008). Hidroponik berasal dari kata Hydro (air) dan Ponics (pengerjaaan), Pada perkembangan selanjutnya orang mulai mencoba media tanam yang lain, kemudian membandingkan keuntungan dan kerugiannya, sehingga selain media tanam air (kultur air) dipakai juga media pasir (kultur pasir) dan bahan porus (Kultur agregat) seperti kerikil, pecahan genteng, pecahan batu bata, serbuk kayu, arang, sekam dan lain-lain.

Sejarah hidroponik dimulai pada 3 abad yang lalu, pada tahun 1669 di Inggris sudah dilakukan pengujian tanaman hidroponik dalam laboratorium. Kemajuan yang sangat berpengaruh terjadi pada tahun 1936, Dr. W.F. Gericke di California berhasil menumbuhkan terong setinggi $3 \mathrm{~m}$ dan berbuah lebat dalam bak berisi air mineral. Pada tahun 1950 Jepang secara besar-besaran menyebarkan cara bercocok tanam hidroponik untuk mensuplai sayuran bagi tentara pendudukan Amerika Serikat (Wijayani, \& Wahyu, 2005). Dari sini hidroponik terus menyebar ke berbagai negara. Di Indonesia hidroponik mulai dikembangkan pada sekitar tahun 1980. Tanaman pada media hidroponik memperbanyak keuntungan antara lain, pengontrolan terhadap penyakit seperti bakteri dan sendawan serta hama cacing dan serangga dapat dicegah karena media yang digunakan bukan lagi tanah tetapi media lain yang telah disterilkan terlebih dahulu disamping itu dapat menghemat pemberian dan larutan nutrient (Soesono, 2008).

\section{METODE}

Jenis penelitian ini adalah penelitian eksperimen dengan menggunakan Rancangan Acak Lengkap (RAL) dengan 4 macam perlakuan, 1 perlakuan sebagai kontrol dengan 
masing-masing perlakuan dibuat 3 kali ulangan sehingga akan diperoleh 12 pot percobaan. Adapun rancangan peneliti sebagai berikut:
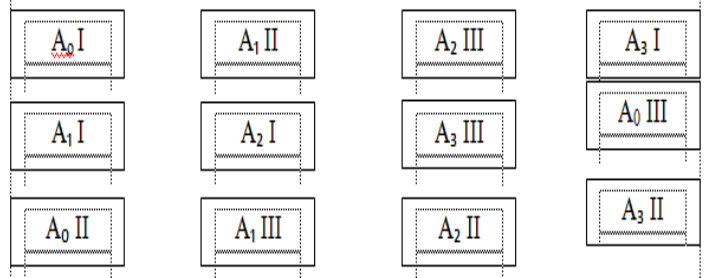

Gambar 1. Rancangan penelitian

\section{Keterangan :}

$\mathrm{A}_{0}$ : Perlakuan menggukan hidroponik media tanam pecahan batu bata dan air $1 \mathrm{cc} / 100 \mathrm{ml}$ air

$\mathrm{A}_{1}$ : $\quad$ Perlakuan menggukan hidroponik media tanam abu gosok atau arang sekam dan air $1 \mathrm{cc} / 100 \mathrm{ml}$ air

$\mathrm{A}_{2}$ : Perlakuan menggukan hidroponik media tanam serbuk kayu + air 1cc/100ml air sebagai kontrol

$\mathrm{A}_{3}$ : Perlakuan menggukan hidroponik media tanam pasir dan air $1 \mathrm{cc} / 100 \mathrm{ml}$ air

Alat dan Bahan yang digunakan adalah Ember, Cangkul, Timba Plastik, Penggaris, Buku Tulis, Pulpen. Sedangkan Bahan yang digunakan adalah Bibit Terong, Pupuk NPK, Urea, KCL dan SP-18, Media Arang Sekam (Abu Gosok), Pecahan Batu Bata, Pupuk Organik (Bokasi), dan Pasir Steril, Polybag 40 x $35 \mathrm{~cm}$, Ajir Bambu, dan Tali Rafia.

Analisa yang digunakan dalam peneltian ini adalah analisa of variance (ANOVA). Melalui analisa varian ini akan ditemukan hasil uji F-nya beda nyata atau tidak.

\section{HASIL DAN PEMBAHASAN}

Pertumbuhan merupakan suatu proses perubahan ukuran organ-organ tanaman akibat adanya penambahan ukuran sel yang mencerminkan proses pertumbuhan (Salisbury \& Ross, 1995). Menurut Azmin et al (2015) Keberhasilan perumbuhanm tanaman dapat ditinjau dari berbagai aspek, salah satunya adalah pertumbuhan tinggi, jumlah daun, luas daun berat basa dan berat kering tanaman. Adapun hasil penelitian ini dapat melalui indicator pertumbuhan tanama terong yaitu pada tabel 1.

Tabel 1. Nilai Rata-rata Hasil Pengamatan Umur 6 HST

\begin{tabular}{|c|c|c|c|}
\hline $\begin{array}{c}\text { Perla- } \\
\text { kuan }\end{array}$ & $\begin{array}{c}\text { Rata-rata tinggi } \\
\text { tanaman }(\mathbf{c m})\end{array}$ & $\begin{array}{c}\text { Jumlah } \\
\text { daun } \\
\text { (helai) }\end{array}$ & $\begin{array}{c}\text { Jumlah } \\
\text { Cabang }\end{array}$ \\
\hline A0 & 32,2 & 3,67 & 2,00 \\
\hline A1 & 33,00 & 19,00 & 12,33 \\
\hline A2 & 48,90 & 24,67 & 16,67 \\
\hline $\mathbf{A 3}$ & 61,27 & 3.38 & 21,67 \\
\hline
\end{tabular}

\section{Tinggi tanaman terong}

Penggunaan media tanaman hidroponik yang berbeda akan berpengaruh terhadap tinggi tanaman terong (Solanum melongena), ini dibuktikan dengan hasil pengamatan terhadap tinggi tanaman terong (Solanum melongena) pada usia 2 minggu, empat minggu dan enam minggu setelah tanam menunjukkan $\mathrm{f}_{\text {hitung }}$ lebih besar dari $\mathrm{f}_{\text {tabel. }}$. Hasil penelitian ini didukung dengan hasil penelitian Azmin et al (2015) mengatakan bahwa salah satu peran penting unsur hara adalah membantu proses 
pembentukan energi dalam proses glikolisis. Energi dari proses oksidasi glukosa (glikolisis) dan proses fotosintesis digunakan untuk meningkatkan pertumbuhan tanaman carica, dimana unsur $\mathrm{P}$ diubah menjadi suatu ikatan pirofosfat dalam bentuk adenosine trifosfat (ATP) dan ADP

Pada umur 2 minggu setelah tanam dengan nilai $\mathrm{F}_{\text {Hitung }}>\mathrm{F}_{\text {Tabel }}(8,13>4,07)$, sementara pada usia tanaman empat minggu setelah tanam menunjukkan nilai $F_{\text {hitung }}$ sebesar 7,99 dengan perbandingan karena $\mathrm{F}_{\text {Hitung }}(7,99)$ $>\mathrm{F}_{\text {Tabel }}(4,07)$ dan minggu keenam setelah tanam menunjukkan $\mathrm{F}_{\text {Hitung }}>\mathrm{F}_{\text {Tabel }}(14,34>$ 4,07). Dari ketiga pengukuran tersebut di atas menunjukkan bahwa secara keseluruhan penggunaan media tanam hidroponik yang berbeda berpengaruh terhadap pertumbuhan tanaman terong (Solanum melongena) terutama terhadap tinggi tanaman terong (Solanum melongena).

Sementara untuk setiap perlakuan pada setiap media yang digunakan karena hasil pengukuran menunjukkan hasil yang sama maka dapat disimpulkan bahwa rata-rata tinggi tanaman minggu kedua, minggu keempat dan minggu keenam setelah tanam pada masingmasing perlakuan berturut-turut menunjukkan hasil yaitu: untuk perlakuan dengan menggunakan media tanam pasir + air $1 \mathrm{cc} / 100 \mathrm{ml}$ air yaitu A3 sebagai media yang sangat mendukung pertumbuhan tanaman terong (Solanum melongena) diperoleh rata-rata tinggi tanaman $4,33 \mathrm{~cm}, 5,67 \mathrm{~cm}$ dan $7,33 \mathrm{~cm}$, kemudian untuk perlakuan dengan menggunakan media tanam abu gosok atau arang sekam dan air 1cc/100ml air (A2) dengan rata-rata tinggi tanaman $3,33 \mathrm{~cm}, 4,00 \mathrm{~cm}, 5,33$ $\mathrm{cm}$, diikuti perlakuan dengan menggunakan media tanam serbuk kayu dan air 1cc/100ml air (A1) dengan rata-rata tinggi tanaman $2,67 \mathrm{~cm}$, 3,67 $\mathrm{cm}$ dan 4,67 $\mathrm{cm}$ dan terakhir perlakuan dengan menggukan media tanam pecahan batu bata dan air 1cc/100ml air (A0) dengan rata-rata tinggi tanaman $2,00 \mathrm{~cm}, 3,33 \mathrm{~cm}$ dan $4,33 \mathrm{~cm}$.

Hasil penelitian ini juga didukung oleh pendapat Wuryaningih (1994) bahwa media hidroponik sering digunakan sebagai media tanam alternatif untuk menggantikan fungsi tanah. Sejauh ini, pasir dianggap memadai dan sesuai jika digunakan sebagai media untuk penyemaian benih, pertumbuhan bibit tanaman, dan perakaran setek batang tanaman. Sifatnya yang cepat kering akan memudahkan proses pengangkatan bibit tanaman yang dianggap sudah cukup umur untuk dipindahkan ke media lain. Sementara bobot pasir yang cukup berat akan mempermudah tegaknya batang.

\section{Jumlah daun tanaman terong}

Penggunaan media tanaman hidroponik yang berbeda akan berpengaruh terhadap jumlah daun tanaman terong (Solanum melongena), ini dibuktikan dengan hasil pengamatan terhadap jumlah daun tanaman 
terong (Solanum melongena) pada usia dua minggu, empat minggu dan enam minggu setelah tanam menunjukkan $\mathrm{f}_{\text {hitung }}$ lebih besar dari $\mathrm{f}_{\text {tabel }}$. Pada umur 2 minggu setelah tanam dengan nilai $\mathrm{F}_{\text {Hitung }}>\mathrm{F}_{\text {Tabel }}(17,00>4,07)$, sementara pada usia tanaman empat minggu setelah tanam menunjukkan nilai $F_{\text {hitung }}$ sebesar 7,99 dengan perbandingan karena $\mathrm{F}_{\text {Hitung }}(7,58)$ $>\mathrm{F}_{\text {Tabel }}(4,07)$ dan minggu keenam setelah tanam menunjukkan $\mathrm{F}_{\text {Hitung }}>\mathrm{F}_{\text {Tabel }}(6,44>$ 4,07). Dari ketiga pengukuran tersebut di atas menunjukkan bahwa secara keseluruhan penggunaan media tanam hidroponik yang berbeda berpengaruh terhadap pertumbuhan tanaman terong (Solanum melongena) terutama terhadap jumlah daun tanaman terong (Solanum melongena).

Menurut (Agoes, 2000) Hal ini membuktikan bahwa penggunaan media tanam pasir, abu gosok atau arang sekam, serbuk kayu dan pecahan batu bata sangat efektif dalam menunjang pertumbuhan jumlah daun tanaman terong (Solanum melongena). Sebenarnya untuk penggunaan media pasir secara tunggal tidak mampu menunjang pertumbuhan tanaman secara umum namun untuk budidaya terong hal ini dimungkinkan karena pada biji terong yang memiliki bentuk seperti ginjal, ringan, berbulu, akan menunjang penggunaan media pasir karena akan mengingat pasir sehingga media pasir sangat cocok untuk pertumbuhan tanaman tomat

\section{Jumlah cabang tanaman terong}

Penggunaan media tanaman hidroponik yang berbeda akan berpengaruh terhadap jumlah cabang tanaman terong (Evanita, 2014). ini dibuktikan dengan hasil pengamatan terhadap jumlah cabang tanaman terong (Solanum melongena) pada usia dua minggu, empat minggu dan enam minggu setelah tanam menunjukkan $\mathrm{f}_{\text {hitung }}$ lebih besar dari $\mathrm{f}_{\text {tabel. }}$.

Pada umur 2 minggu setelah tanam dengan nilai $\mathrm{F}_{\text {Hitung }}>\mathrm{F}_{\text {Tabel }}(11,89>4,07)$, sementara pada usia tanaman empat minggu setelah tanam menunjukkan nilai $\mathrm{F}_{\text {hitung }}$ sebesar 6,44 dengan perbandingan karena $\mathrm{F}_{\text {Hitung }}(6,44)$ $>\mathrm{F}_{\text {Tabel }}(4,07)$ dan minggu keenam setelah tanam menunjukkan $\mathrm{F}_{\text {Hitung }}>\mathrm{F}_{\text {Tabel }}(16,25>$ 4,07). Dari ketiga pengukuran tersebut di atas menunjukkan bahwa secara keseluruhan penggunaan media tanam hidroponik yang berbeda berpengaruh terhadap pertumbuhan tanaman terong (Solanum melongena) terutama terhadap jumlah cabang tanaman terong (Solanum melongena).

\section{KESIMPULAN}

Berdasarkan hasil penelitian dan pembahasan, maka dapat disimpulkan bahwa:

1. Penggunaan media tanaman hidroponik yang berbeda akan berpengaruh terhadap tinggi tanaman terong (Solanum melongena), ini dibuktikan dengan hasil pengamatan terhadap tinggi tanaman terong (Solanum 
melongena) pada usia 2 minggu, empat minggu dan enam minggu setelah tanam menunjukkan $\mathrm{f}_{\text {hitung }}$ lebih besar dari $\mathrm{f}_{\text {tabel. }}$. Hal ini didukung dengan hasil penelitian pada umur 2 minggu setelah tanam dengan nilai $\mathrm{F}_{\text {Hitung }}>\mathrm{F}_{\text {Tabel }}(8,13>4,07)$, sementara pada usia tanaman empat minggu setelah tanam menunjukkan nilai $F_{\text {hitung }}$ sebesar 7,99 dengan perbandingan karena $\mathrm{F}_{\text {Hitung }}(7,99)>$ $\mathrm{F}_{\text {Tabel }}(4,07)$ dan minggu keenam setelah tanam menunjukkan $\mathrm{F}_{\text {Hitung }}>\mathrm{F}_{\text {Tabel }}(14,34>$ $4,07)$.

2. Penggunaan media tanaman hidroponik yang berbeda akan berpengaruh terhadap jumlah daun tanaman terong (Solanum melongena), ini dibuktikan dengan hasil pengamatan terhadap jumlah daun tanaman terong (Solanum melongena) pada usia dua minggu, empat minggu dan enam minggu setelah tanam menunjukkan $\mathrm{f}_{\text {hitung }}$ lebih besar dari $\mathrm{f}$ tabel. Dimana pada umur 2 minggu setelah tanam dengan nilai $\mathrm{F}_{\text {Hitung }}>\mathrm{F}_{\text {Tabel }}(17,00>$ 4,07), sementara pada usia tanaman empat minggu setelah tanam menunjukkan nilai $F_{\text {hitung }}$ sebesar 7,99 dengan perbandingan karena $F_{\text {Hitung }}(7,58)>F_{\text {Tabel }}(4,07)$ dan minggu keenam setelah tanam menunjukkan $\mathrm{F}_{\text {Hitung }}>\mathrm{F}_{\text {Tabel }}(6,44>4,07)$.

3. Penggunaan media tanaman hidroponik yang berbeda akan berpengaruh terhadap jumlah cabang tanaman terong (Solanum melongena), ini dibuktikan dengan hasil pengamatan terhadap jumlah cabang tanaman terong (Solanum melongena) pada usia dua minggu, empat minggu dan enam minggu setelah tanam menunjukkan $\mathrm{f}_{\text {hitung }}$ lebih besar dari $f_{\text {tabel. }}$. Dimana pada umur 2 minggu setelah tanam dengan nilai $\mathrm{F}_{\text {Hitung }}>$ $\mathrm{F}_{\text {Tabel }}(11,89>4,07)$, sementara pada usia tanaman empat minggu setelah tanam menunjukkan nilai $F_{\text {hitung }}$ sebesar 6,44 dengan perbandingan karena $F_{\text {Hitung }}(6,44)>$ $\mathrm{F}_{\text {Tabel }}(4,07)$ dan minggu keenam setelah tanam menunjukkan $\mathrm{F}_{\text {Hitung }}>\mathrm{F}_{\text {Tabel }}(16,25>$ 4,07).

\section{DAFTAR PUSTAKA}

Azmin, N., \& Sugiyarto., Marsusi. (2015). Pertumbuhan Carica (Carica pubescens) Dengan Perlakuan Dosis Pupuk Fospor Dan Kalium Untuk Mendukung Keberhasilan Transplantasi Di Lereng Gunung Lawu. Jurnal EL-VIVO. ol.3, No.1, hal $34-40$

Agoes, H. (2000). Mengenal Hidroponik Bercocok Tanam Tanpa Tanah. Agromedia Pustaka. Jakarta.

Agus, (2008). Budidaya Terong. Nobel Edumedia : Bandung

Muchtadi, D. (2000). Sayur-sayuran Sumber Serat dan Antioksidan : Mencegah Penyakit Degeneratif. Jurusan Teknologi Pangan dan Gizi. Fakultas Teknologi Pertanian. IPB. Bogor

Rukmana R. (1994). Bertanam Terong. Kanisius. Yogyakarta. 